\title{
E-Business In Central And Eastern European Countries: Measures For Business Performance Analysis
}

Metka Tekavčič, (E-mail: metka.tekavcic@uni-lj.si), University of Ljubljana, Slovenia Mojca Marc, (E-mail: mojca.marc@uni-lj.si), University of Ljubljana, Slovenia

\begin{abstract}
Even though Internet usage in CEE population is increasing, it is below European average. The majority of companies are recognizing the need to do business electronically. However, most companies are currently still at the beginning stages: e-business does not reach operational processes indepth. Changes in the way a business is carried out influence business performance analysis. We argue that this happens mainly in the areas of customers, employees, intangibles, operational processes and also finance. For CEE e-business companies, at their present stage of development, the most important area is customer analysis. We present and discuss a number of measures that can be used to evaluate these areas and draw attention to some differences between traditional and e-business companies.
\end{abstract}

\section{Introduction}

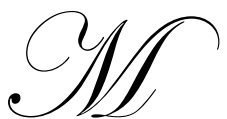

odern companies increasingly depend on information technology, which is no longer only a decision-supporting tool, but is gradually becoming also the nucleus around which a business is created. The evolution of information technology has also changed the way consumers behave and has led to e-business, which is steadily becoming the natural and ubiquitous way in which a business is carried out. This course of action has caused many changes in business environment and business processes that need to be accounted for by companies themselves and also by "outside" analysts. E-business performance analysis (e-BPA) has increased, but it is mainly in the domain of consulting firms and investment banks as the theoretical basis is still in its infancy. The recent fluctuations on world (and especially American) stock markets showed there are still many puzzles that need to be resolved. BPA is well developed in Slovenia and for this reason we join the world discussion on e-BPA first on theoretical grounds, but bearing in mind the actual state of e-business in CEE countries. This paper attempts to identify the areas that are essential for effective business performance analysis of e-business companies in CEE countries. Furthermore, we try to give an overview of measures and ratios that are appropriate for monitoring and evaluating these areas.

\section{Characteristics of Internet Usage and E-Business in CEE Countries}

When implementing BPA, it is necessary to take into account broader conditions in which a company operates. In the beginning of this paper, we therefore present some facts about Internet usage in CEE countries and the characteristics of e-business in companies, operating in these countries, with a special emphasis on Slovenia.

\subsection{Internet Usage in the Population in CEE Countries}

Although the use of information and communication technology is increasing, CEE countries still lag behind the leading parts of the world: United States, Western Europe and Scandinavian countries. According to a Center for democracy and Technology report (CDT Policy Post, 2000) a major barrier to Internet usage in many

Readers with comments or questions are encouraged to contact the author via email. 
countries is the poor state of the underlying telecommunications infrastructure. Most people, particularly residential users are currently dependent on telephone dial-up connections to the Internet. Throughout the CEE region, teledensity rates are low, service quality is often poor and there are long waiting lists for installation of new telephone lines. A second major barrier to Internet usage is the practice of per-minute charges for local calls, which makes connection time prohibitively expensive for many.

At the end of 2000, the overall number of PCs within the CEEC was estimated at 11 million, of which approximately $70 \%$ were business PCs and the remaining $30 \%$ were home PCs. The PC penetration rate (the number of PCs per 100 inhabitants) in the region was 10, ranging from lowest 0,15 (Albania) to highest 28 (Slovenia) (see Table 1). The corresponding number for the EU was about $47.4 \%$ of the population and for the US $50 \%$ of households. The total number of Internet users in the CEEC at the end of 2000 was estimated at 9.6 million, that means that about $8 \%$ of the population was accessing the Web at least once a month. Poland, Czech Republic and Romania are top 3 countries in terms of Internet users; however, Estonia had the highest Internet penetration (28 Internet users per 100 inhabitants). The Internet penetration in Poland and Czech Republic was above region's average, while Romania considerably lagged behind it. In October 2000, $27.5 \%$ of the EU population and 53\% of the US population was on-line in the last 14 days. In the period 1999-2000, the average growth of Internet usage in the CEE region was equal to $86 \%$, ranging from $10 \%$ in Romania to $400 \%$ in Czech Republic (ESIS II Report, 2001).

In the following paragraphs we present some results of the research project RIS (Raba Interneta v Sloveniji - Internet Usage in Slovenia) ${ }^{1}$, which has been carried out every year since 1996 and the results of Czech Internet surveys conducted by VIP (Virtual Information Park $^{2}$ ).

In its beginning, the spread of Internet usage in Slovenia was one of the fastest in Europe, due to the availability of new technologies, politics of $\mathrm{Arnes}^{3}$ and relatively low priced telephone services (Vehovar, 2000). However, after 1998 the growth in Internet usage, compared to European average, has dramatically slowed down: in 1998 the share of Internet users in Slovenian population (15 years and older) was at the European average level, whereas in July 2001 it was about half as big (25\% as opposed to 47\%). Nevertheless, in 2001 the number of Internet users increased by 40\%. For instance, in November 2001 there were 450,000 active (monthly) users and about 660,000 persons have used the Internet at least once (Vehovar, Murgelj, 2001). It is estimated that there will be around $600,000-700,000$ active users at the end of 2002.

In Slovenia, early Internet absorption was primarily typical of male, urban, educated and computer-savvy users, with a good command of English, the rest of population has somewhat lagged behind. Similar conclusions were found for a typical Internet user in the Czech Republic, Slovakia and Hungary being a young man who has finished university with a technical orientation, generally working in towns and in organizations dealing with IT or generally services (Feindt, Culpin, 1998). However, recent results for Czech Republic demonstrate a considerably larger number of women and a change in average age to about 30 years (VIP, 2000). Similar tendencies can be observed in Slovenia.

The major purpose of regular usage in Slovenia is business, personal (communication, hobbies etc.) and general information search. In the first half of 2001 about $12 \%$ of active users (i. e. 50,000 users) purchased items over the Internet over the last 12 months (RIS 2000/2001). Almost half of them shop exclusively at non-Slovenian websites. RIS researchers estimated that overall e-sales in 2001 amounted to near SIT 2 billion (about EUR 9 million). In general, e-shoppers are relatively satisfied with the state of e-commerce in Slovenia, but they find commercial e-mails following accomplished purchases especially disturbing. The main hindrances for more extensive use of

\footnotetext{
${ }^{1}$ The RIS project is an academic and nonprofit research project at the University of Ljubljana (Slovenia), Faculty of Social Sciences. It is dedicated to gather, interconnect and analyze empirical data connected with the relevant aspects of Internet. See URL: [http://www.ris.org].

${ }^{2}$ Virtual Information Park (VIP) is the information service (on the Net since 1995) focused on the information economy and society development and the topics of Internet strategies, e-business and virtual education (Czech Republic). See URL: [http://www.park.cz/pruzkum/e/vipe.asp].

${ }^{3}$ Academic and Research Network of Slovenia, an institution whose main task is to develop, operate and manage the communication and information network for education and research.
} 
e-shopping are: delivery problems, the fact that one cannot touch the items for sale, distrust in paying process security and the like ${ }^{4}$.

Typical Czech Internet users use the Internet both at work and at home, one to two hours daily, especially the services WWW and e-mail. Their major motivation is retrieving information for personal needs and work as well as the need to communicate. On WWW users are above all interested in information regarding culture, entertainment, sport, news and professional information about products. Approximately half of respondents have had their own experience with online purchase; others are seriously interested in using this type of shopping or at least to try it out. The major obstacle in shopping through the Internet is the fear of transaction fraud. The most popular online shopping is above all books as well as reservations of travel/admission tickets.

\subsection{E-business in CEE Countries}

Overall, we can say that in the majority of CEE countries the utilization and deployment of e-business remains quite low, especially if compared to EU or U. S., largely due to high cost and telecom monopolies, the lack of support and use by the governments, an inadequate legal and regulatory framework and unfriendly (often overly burdensome) business environment. A report by McConnell International on E-readiness rated Estonia high in three of five categories observed, namely e-leadership, human capital and business climate (McConnell, 2000). The other two categories were connectivity and information security. The survey found that Bulgaria, the Czech Republic, Hungary, Latvia, Lithuania, Poland, Slovakia and Slovenia need to make improvements in the conditions necessary to support electronic business and government.

There is not much specific statistical information on e-business (or on e-commerce) development in Central and Eastern Europe. Two often-cited indicators that can be used to assess the supply of information available through the Internet and can be compared internationally are the number of Internet hosts and secure servers (Coppel, 2000). There is already a wide gap between US and EU in the number of Internet hosts (the number of European Internet hosts is only about one third of the American), but the CEE countries are even further behind, with the exception of Estonia, which outpaced even EU per capita average. The gap in the amount of information available through the Internet comparing EU and CEE is even more obvious when we consider the number of web sites. There are only 14 web sites per every 10,000 inhabitants in CEE, while the corresponding number for EU is 164 web sites.

Secure servers allow users to encrypt information on, for instance, credit card data, which facilitates ecommerce. A count of secure servers, therefore, gives a reasonable measure of the distribution of e-commerce activities across countries. The figures in Table 2 demonstrate that about half of secure servers in CEE are Polish or Czech, but it is again Estonia and Slovenia that have the most secure servers per capita, reaching approximately $80 \%$ of EU per capita average.

A study by IDC (Moore, 2001) found out that online purchase by Slovenian consumers represented two thirds of all B2C eCommerce generated in the researched region (Bulgaria, Romania, Slovenia and Croatia) in 2001. According to IDC 5 , the total value of e-commerce transactions in the four Visegrad countries ${ }^{6}$ of Central Europe in 2000 was EUR 117 million, for 2001 they predicted a jump to over EUR 760 million. B2B purchasing was predicted to experience the highest growth and account for two thirds of transactions in 2001, online procurement as part of a supply chain should represent one fifth of the total, while the remaining EUR 117 million should come from B2C consumer spending. We were not able to establish to what extent these predictions were realized.

Table 1: General PC and Internet usage indictors for selected CEE countries.

\footnotetext{
${ }^{4}$ See URL: [http://www.ris.org/si/ris2000/novice/20010412.html].

${ }^{5}$ See URL: [http://www.altevie.net/mediagraphix/europeaninternetstats/].

${ }^{6}$ Visegrad countries are Poland, Hungary, Slovakia and the Czech Republic.
} 


\begin{tabular}{|c|c|c|c|c|c|c|c|c|c|}
\hline \multirow[b]{2}{*}{ Poland } & \multicolumn{2}{|c|}{$\begin{array}{c}\text { Population } \\
\text { in mio } \\
(2000)\end{array}$} & \multicolumn{2}{|c|}{$\begin{array}{c}\text { Number of PCs } \\
\text { in 000 } \\
(2000)\end{array}$} & \multirow{2}{*}{$\begin{array}{c}\frac{\text { Home }}{\text { Business }} \\
\frac{20 \%}{80 \%}\end{array}$} & \multirow{2}{*}{$\begin{array}{c}\text { PC } \\
\text { penetration } \\
\text { (Number of } \\
\text { PCs per } 100 \\
\text { inhabitants) } \\
17\end{array}$} & \multicolumn{2}{|c|}{$\begin{array}{l}\text { Internet users } \\
\text { in } \mathbf{0 0 0} \\
(2000)\end{array}$} & \multirow{2}{*}{$\begin{array}{c}\text { Internet pene- } \\
\text { tration } \\
\text { (Number of } \\
\text { Internet users } \\
\text { per } 100 \\
\text { inhabitants) } \\
13\end{array}$} \\
\hline & 38.65 & $33 \%$ & 6,400 & $55 \%$ & & & 5,200 & $53 \%$ & \\
\hline Romania & 22.5 & $19 \%$ & 713 & $6 \%$ & $\frac{31 \%}{69 \%}$ & 3 & 690 & $7 \%$ & 3 \\
\hline Czech Republic & 10.272 & $9 \%$ & 342 & $12 \%$ & $\frac{27 \%}{73 \%}$ & 13 & 1,000 & $10 \%$ & 10 \\
\hline Hungary & 10.043 & $8 \%$ & 360 & $3 \%$ & n.a. & 4 & 650,000 & $7 \%$ & 6 \\
\hline Bulgaria & 8.175 & $7 \%$ & 361 & $3 \%$ & n.a. & 4 & 430 & $4 \%$ & 5 \\
\hline Slovakia & 5.398 & $5 \%$ & 716 & $6 \%$ & $\frac{22 \%}{78 \%}$ & 13 & $600 *$ & $6 \%$ & 11 \\
\hline Bosnia & 3.84 & 35 & n.a. & n.a. & n.a. & 0.26 & 6 & $0 \%$ & 0 \\
\hline Lithuania & 3.7 & $3 \%$ & $240 *$ & $2 \%$ & $\frac{37 \%}{63 \%}$ & 6 & $180 *$ & $2 \%$ & 5 \\
\hline Albania & 3.37 & $3 \%$ & 5 & $0 \%$ & n.a. & 0.15 & 5.5 & $0 \%$ & 0.16 \\
\hline Latvia & 2.37 & $2 \%$ & $220 *$ & $2 \%$ & $\frac{21 \%}{79 \%}$ & 9 & 150 & $2 \%$ & 6 \\
\hline FRY Macedonia & 2.026 & $2 \%$ & n.a. & n.a. & n.a. & n.a. & 20 & $0 \%$ & 1 \\
\hline Slovenia & 1.99 & $2 \%$ & 548 & $5 \%$ & $\frac{44 \%}{56 \%}$ & 28 & 300 & $3 \%$ & 15 \\
\hline Estonia & 1.44 & $1 \%$ & 60 & $1 \%$ & n.a. & 4 & 380 & $4 \%$ & 26 \\
\hline Croatia & 4.481 & $4 \%$ & 640 & $6 \%$ & n.a. & 14 & 200 & $2 \%$. & 4 \\
\hline Region & 118.237 & $100 \%$ & 11,605 & $100 \%$ & n.a. & 10 & $9,811,500$ & $100 \%$ & 8 \\
\hline EU & & & 106 & & n.a. & 47 & 89,723 &, 000 & 28 \\
\hline USA & & & $\mathrm{n}$ & & n.a. & $50 \triangleleft$ & 134,60 & 0,000 & 53 \\
\hline
\end{tabular}

Sources: ESIS II Report, 2001 and ESIS homepage (Data by country); Hobley, 2001; Computer Industry Almanac Inc., 2001; Eurostat, 2002; The Center for Democracy and Technology (Country details), 2000; OECD, 2000; U. S. Agency for International Development, 2000.

* year 1999.

- per 100 households.

Note: All data have been collected from readily publicly available sources of information. As they depend on definitions that are not standardized in all countries, or, in some cases on estimates, and also due to the difficulty to obtain statistical data and series in several countries covered, these indicators should be considered only as indicative of general situation.

In the case of Slovenia the RIS project results (December 2000/January 2001) ${ }^{7}$ show that practically all big companies and the majority of smaller ones use the Internet, mainly to gather business information and com-

\footnotetext{
${ }^{7}$ See URL: [http://www.ris.org/publikacije/j_eposlovnj.htm].
} 
municate, but rarely to carry out business processes. Only $10 \%$ of companies that have Internet access generate e-business revenues, which typically represent less than $1 \%$ of total revenues, but the majority of companies believe that Internet has important influence on their business. Electronic banking transactions are widely used, while on-line sale and electronic ordering (e-procurement) are limited to a few percents of all companies or orders, respectively.

Table 2: Number of Internet hosts and secure servers in selected CEE countries.

\begin{tabular}{|c|c|c|c|c|c|c|c|c|c|c|}
\hline \multirow[b]{2}{*}{ Poland } & \multirow{2}{*}{\begin{tabular}{|c}
$\begin{array}{c}\text { Internet pene- } \\
\text { tration in } \\
\text { companies } \\
\text { (end 2000) }\end{array}$ \\
11
\end{tabular}} & \multicolumn{2}{|c|}{$\begin{array}{c}\text { Internet } \\
\text { hosts } \\
\text { (June 2002) }\end{array}$} & \multirow{2}{*}{\begin{tabular}{|c} 
per 100 \\
inhabitants
\end{tabular}} & \multicolumn{2}{|c|}{$\begin{array}{c}\text { Secure servers } \\
\text { (March 2000) }\end{array}$} & \multirow{2}{*}{$\left|\begin{array}{c}\text { per million } \\
\text { inhabitants }\end{array}\right|$} & \multicolumn{2}{|c|}{$\begin{array}{l}\text { Websites } \\
\text { (July 2002) }\end{array}$} & \multirow{2}{*}{\begin{tabular}{|c|}
$\begin{array}{c}\text { per } 10,000 \\
\text { inhabitants }\end{array}$ \\
10
\end{tabular}} \\
\hline & & 526,258 & $41 \%$ & & 326 & $27 \%$ & & 37,931 & $23 \%$ & \\
\hline Romania & n.a. & 45,081 & $3 \%$ & 0.2 & 53 & $4 \%$ & 2 & 6,496 & $4 \%$ & 3 \\
\hline Czech Republic & 95 & 215,429 & $17 \%$ & 2.1 & 273 & $23 \%$ & 27 & 47,644 & $28 \%$ & 46 \\
\hline Hungary & n.a. & 172,363 & $13 \%$ & 1.7 & 127 & $11 \%$ & 13 & 33,721 & $20 \%$ & 33 \\
\hline Bulgaria & n.a. & 29,840 & $2 \%$ & 0.4 & 18 & $1 \%$ & 2 & 914 & $1 \%$ & 1 \\
\hline Slovakia & n.a. & 80,962 & $6 \%$ & 1.5 & 79 & $7 \%$ & 15 & 18,803 & $11 \%$ & 35 \\
\hline Bosnia & n.a. & 5,041 & $0 \%$ & 0.1 & n.a. & & n.a. & 693 & $0 \%$ & 2 \\
\hline Lithuania & 60 & 40,310 & $3 \%$ & 1.1 & 43 & $4 \%$ & 12 & 3,523 & $2 \%$ & 10 \\
\hline Albania & n.a. & 205 & $0 \%$ & 0.0 & 1 & $0 \%$ & 0.3 & 54 & $0 \%$ & 0 \\
\hline Latvia & 45 & 31,619 & $2 \%$ & 1.3 & 43 & $4 \%$ & 18 & 4,530 & $3 \%$ & 19 \\
\hline FRY Macedonia & n.a. & 2,753 & $0 \%$ & 0.1 & n.a. & & n.a. & 166 & $0 \%$ & 1 \\
\hline \multirow[t]{3}{*}{ Slovenia } & large 100 & 33,581 & $3 \%$ & 1.7 & 102 & $8 \%$ & 52 & 3,847 & $2 \%$ & 19 \\
\hline & medium 98 & & & & & & & & & \\
\hline & small 85 & & & & & & & & & \\
\hline Estonia & n.a. & 88,318 & $7 \%$ & 6.2 & 80 & $7 \%$ & 56 & 3,761 & $2 \%$ & 26 \\
\hline Croatia & n.a. & 26,455 & $2 \%$ & 0.6 & 61 & $5 \%$ & 14 & 6,442 & $4 \%$ & 14 \\
\hline Region & n.a. & $1,298,215$ & $100 \%$ & 1.3 & 1,206 & $100 \%$ & 11 & $1,993,698$ & $100 \%$ & 14 \\
\hline EU & $70 *$ & \multicolumn{2}{|c|}{$13,463,000$} & 4 & \multicolumn{2}{|c|}{19,636} & 65 & \multicolumn{2}{|c|}{$4,968,564$} & 164 \\
\hline U.S. & $85^{*}$ & & & 12 & 78, & & 282 & & & \\
\hline
\end{tabular}

Sources: Netcraft, 2001; RIPE, 2002; ESIS homepage (Data by country); Hobley, 2001;United States Internet Council \& ITTA Inc., 2000; Coppel, 2000.

* small and medium enterprises.

Note: All data have been collected from readily publicly available sources of information. As they depend on definitions that are not standardized in all countries, or, in some cases on estimates, and also due to the difficulty to obtain statistical data and series in several countries covered, these indicators should be considered only as indicative of general situation.

A half of companies with Internet access use e-business (i. e. document exchange with up to 5 partners), the reasons for its implementation being better service quality, flexibility, competitive advantage and new markets, followed by somewhat less important cost reduction and sale increase. Most of them consider that e-business implementation should reduce costs by more than $10 \%$ to be justified. Beside that, companies listed human and financial 
resources shortage as main obstacles to greater implementation. Companies using e-business think that it will be the prevalent standard of doing business for their industry in the period of 2-3 years.

\section{The Influence of e-Business on Business Performance Analysis}

We found that the importance of the Internet and e-business increases in the population (or end consumers) as well as in companies in CEE region. Greater use of information technology is associated with more or less radical changes in the way companies operate in such environment, what triggers the need to adjust and supplement BPA process. In this section we briefly explain the influence of e-business on business analysis and continue with a review of some analytical approaches and frameworks that are used (or recommended) to analyze e-business performance. We determine relevant areas, which are especially important for e-BPA or where the biggest changes occur.

BPA is a scientific discipline that attempts to identify how to improve business performance and consists of five components (Pučko, 2001): the aim of BPA (to identify interdependencies or create insight into business operations), the purpose of BPA (to evaluate and improve business performance), the object, the method and the process. E-business affects primarily the following elements (Tekavčič, 2000).

1. The process of BPA: because of the information technology possibilities and intense competition in ebusiness environment, the process is (and has to be) notably faster, on the other hand data availability, amount and quality are greater, what is especially beneficial to comparative analysis across geographical areas or companies (benchmark analysis).

2. The type of elements (problems) that need to be analyzed: there is still a lot of work to be done in this area; because e-business companies differentiate them from more traditional companies in the structure of their customers and employees, these are already two important areas to analyze.

BPA is typically based on accounting information and focused on short to middle term. Because of the nature and characteristics of accounting principles, these are ever less suitable even for traditional companies, let alone the conditions which e-business companies operate in. Therefore, it is plausible that measures, ratios and other indicators of an e-business company performance, based on accounting or financial data, give a rather distorted image of companies, whose essence is in information technology, know-how and human capital. Besides, even though the short term, operational efficiency and effectiveness is important, this is not enough for a successful business, which also needs a good strategy and clear vision. Because of that we can see a growing popularity of comprehensive models and frameworks for analytical purposes that incorporate more than one aspect of business performance (typically accounting or financial), some of them also try to link it with strategic aspects.

Development and research in the field of BPA is primarily the domain of consulting companies, which have practical experience and relatively good data on their clients. Thus a considerable part of proposed and used models or frameworks for BPA in general and e-business in particular comes from their part. We will draw attention to some of them, which are tailored to the case of e-business analysis.

1. The Balanced e-Scorecard (Melymuka, 2001) is an adapted version of the well-known and used Balanced Scorecard approach ${ }^{8}$. It keeps the basic idea behind it and four original aspects: financial, customers, operational, innovation and learning, but develops some new goals and measures that are relevant for e-business (for example infrastructure reliability: time to load a page, network uptime and similar).

2. The Performance Prism (Adams et al., 2000 - 2001) model integrates five aspects of BPA: stakeholders' satisfaction (i. e. customers, partners, regulators, investors, employees), strategies (i. e. business unit, functional), processes (i. e. creating demand, developing new products and services, fulfilling demand, planning and management), capabilities and stakeholders' contribution. Its distinguishing feature is the measuring of stakeholders' contribution, not only satisfaction, what is fairly important for e-business companies, which are to a large extent young companies, in the growth phase, often financed by venture capitalists and highly dependent on small number of employees.

\footnotetext{
${ }^{8}$ See e.g.: Kaplan, Norton, 1996.
} 
3. The e-Metrics Compass (Donath, 1999) comes from professor Mohan Sawhney, who compares e-business companies to knowledge factories, where inputs are the components of intellectual capital, that is human capital (employees), structural capital (intangibles) and relationship capital (customers). The Compass shows how successful performance in all three areas leads to market-to-book ratio, which is what, in his opinion, managers care about the most.

4. The Internet Value Matrix (Cisco Corporation, 2001) is a more strategically oriented approach, but includes also key financial, customer satisfaction and operational metrics for different strategies (operational excellence in two versions: based on frictionless execution or on value innovation, new fundamentals, breakthrough strategy or rational experimentation). It was developed to assist clients in developing and evaluating their Internet strategies.

5. The Digital Value Added (Stern Stewart \& Co., Razorfish Inc., 2001) is a variation of Economic Value Added (EVA) that focuses only on financial aspects of four services: benchmarking current digital initiatives, developing digital metrics, milestones and valuations, breaking down the barriers to execution and strengthening IT government processes.

Based on this short presentation of various concepts, it can be argued that the form of presented concepts is different, the content, however, is not that far apart. All models, except the Digital Value Added, stress the importance of customers, which are becoming more and more demanding, computer-savvy and powerful. Another common feature is financial aspect, not because there would be a lot of change regarding e-business, but because it is still the most universal, consistent language of comparison and the ultimate purpose of any commercial business. Besides, the majority of models incorporate operational excellence (i. e. changes associated with the use of information technology in business processes), intangibles (e. g. software, data bases, domains, brand names) and human capital.

\section{Measures for e-BPA}

In this section we explore the identified important areas of e-BPA and draw attention to some useful measures and ratios for monitoring and evaluating e-business performance in these areas. There is of course a wide variety of measures that can be used for evaluating each area. We try to give a short overview of them, focusing on those that can be useful for e-BPA, especially if used as an addition to traditional, well-known measures. Also, it has to be noted that when performing analysis one must handle companies individually and should not use all listed or possible measures. Instead, one must carefully select measures and ratios that are most appropriate for each individual company.

\subsection{Customers}

Customers have more choice and more information in e-environment, they can perceive and take advantage of price differences easier. There is every indication that the key to e-business success is foremost customer satisfaction and companies start to realize that customers need to be considered as an integral and central part of their business instead of an "outside target". Customer analysis is essential for every business, but e-business companies, especially Internet companies, have the opportunity to develop it much deeper than traditional companies, as they can track their visitors' and customers' clicking through a website. There are basically three critical phases in customer's life cycle (Agrawal et al., 2001): acquiring visitors, converting them into customers and retaining customers.

1. The purpose of visitor acquisition is to get the attention of the target segment of population, trigger activity from the part of a potential buyer and lure him/her into some interaction with the company e.g. to visit the website, to register or to join the forum in exchange for a free download, demo versions and the like. The effectiveness and efficiency of this phase can be estimated by some of the following measures: total site reach, number of visitors, acquisition costs per visitor, frequency (i. e. number of visits per visitor) and duration (i. e. average duration of visit). Companies want their visitors to spend as much as possible time on company's website, therefore Cutler and Sterne (2000) suggest measuring stickiness (i. e. amount of time visitors spend on website), which gives an indication of a website's content effectiveness. Another useful measure they propose is the freshness factor, which measures the effect of resources allocated to constant 
content refreshing. The freshness factor is calculated as a ratio between average number of content refreshments and average number of visits per visitor in a time period. If the ratio is less than 1, visitors on average visit website more frequently than company refreshes its content and vice versa. They know the content and stickiness would be probably lower. Cutler and Sterne believe freshness factor greater than 1.5 indicates inefficiency, as company creates content that visitors don't see.

2. It is the second phase, customer conversion, which has showed it to be the most problematic for ebusiness. Namely, it is typical that companies or websites get a lot of attention from visitors, but only a few percentages decide to actually buy something. A McKinsey survey has demonstrated that on average less than $5 \%$ of visitors will make a purchase, while the best companies have attained a $12 \%$ conversion (Agrawal et al., 2001). Some possible measures for estimating this phase are: number of customers, customer acquisition cost, customer conversion rate, number of transactions per customer, revenue per transaction and per customer, operating income per customer, .... Another e-business phenomenon in this phase is shopping carts abandonment. Boston Consulting Group estimates that users abandon more than $65 \%$ of Web shopping carts before making a purchase online, the main reasons being high shipping prices and shopping prices comparing (Netstatistica, 2001). Cutler and Sterne (2000) suggest using the following measures for monitoring this behavior: the ratio of abandoned shopping carts to completed purchases per day, the number of items and their profile in abandoned carts vs. items in completed purchases, the profile of a shopper vs. a buyer.

3. Retaining customers or customer loyalty is, according to the McKinsey survey, the key to dot-coms' profitability (Agrawal et al, 2001). It is economically more reasonable to retain additional customers than to acquire new ones or to cut expenditure for retaining customers. The best companies in the survey have managed to retain about $60 \%$ of their customers and realized three times bigger profit (before tax) as with one-time customers. Measures of customer retention include: number of repeat-customers, repeat-customer acquisition cost, repeat-customer churn rate, number of transactions per repeat-customer, revenue per transaction and per repeat customer.

4.

\subsection{Operational excellence}

Operational excellence relates foremost to internal business processes, which are essential for a company to reach its business purpose. On the basis of Porter's value chain model, we can find five fundamental internal processes: inbound logistics, operations, marketing and sales, delivery and service. E-business has affected all of these processes and especially their integration and interaction. Internal processes are to a lesser extent parts of a chain, but ideally should form a tight communication network, which is flexible to demands from the inside and outside of the company. One of the great promises of e-business is to cut costs related to these processes, but it should be noted that this is possible only if they are effectively and efficiently founded in the first place. The analysis of internal processes in e-business companies is conceptually not that different from the analysis in traditional companies: three key determinants of every process that have to be monitored are velocity, quality and efficiency. But there are some additional measures that can give a company a clearer picture of what and where the benefits and weaknesses of e-business are.

1. Inbound logistics or procurement is arguably one of the areas where even traditional companies can gain by introducing e-business systems or applications (Bennet, 2001). Scepticism is the result of bad experience with lengthy and costly ERP systems introduction, scruples about security and backup problems and required change of business culture. Nevertheless, some companies' experience demonstrates that automated procurement chains can yield handsome return on investment, because they shorten the procurement process duration, improve inventory control and above all, reduce procurement costs. Some measures that are used to monitor the procurement process are: total duration of the process, share of incorrect or untimely supplies, number of input shortage cases (by reason), share of electronically provided inputs, share of eprocurement costs in total procurement costs, share of suppliers with whom e-procurement is established, inventory level and turnover, costs, prices and business terms achieved by doing business electronically vs. traditionally.

2. Operations transform inputs into final products or services. For new economy companies, mass customization is slowly becoming the new type of operations, which means that operation processes are increasingly 
subordinate to individual customer demands. Influence of e-business on operations is highly related to the nature of business. Furniture manufacturing companies, for instance, may only have electronic systems for processing orders, controlling inventories and quality. ISP providers' operations on the other hand are almost entirely based on ICT. A few of operations-related measures are: total duration of the operation process, total time to complete customer's order, time to load a web page, logicality of website structure (one can measure this through: the share of users that do not follow the expected click-path, the number of "unnecessary" clicks made by users, the share of users that discontinued the process), time to make an order (how much typing needs to be done by user), the percentage of improperly or untimely fulfilled orders, maximum number of orders that can be processed simultaneously, percentage of orders that can be processed/fulfilled online, percentage of cases of data unavailability due to company's server error, percentage of cases of inability to fulfill orders.

3. Operations are followed by sales, delivery, and service. In this section, sales are referred to gathering and processing of orders, billing and payment of products and services. We covered some marketing issues in section 3.1. The main difference between traditional and e-business, regarding sales, is that in the latter sales are integrated into company's central information system (Jerman Blazic, 2001). Namely, there is a direct connection between sales and inventories, production, customers database. In this way a company can maximally adapt to its customers demands. Some measures mentioned in previous sections are also useful when analyzing sales, e.g. time to make an order, the percentage of improperly fulfilled orders etc. Others, somewhat more specific measures, are: share of customers that place orders electronically/online, orders' status, share of customers that are billed electronically/online, share of customers that pay electronically/online, time to execute online payment, number of payment transaction errors, share of transactions settled by barter agreements, receivables turnover. Delivery is becoming one of key competitive advantages in e-environment. Measures that can be used to observe the delivery process are: time necessary to deliver the product or service to the customer, share of untimely and/or incorrect deliveries, delivery costs covered by company and by customers. Service can be carried out electronically/online in the form of FAQ, product support web pages and the like. Some measures for performance evaluation are: time necessary to solve customers' (product related) problems, share of responses to customer's first time request, customers' time spent on support web pages, costs related to service.

\subsection{Human Capital}

Human resources are of even greater strategic importance for e-business companies than for traditional companies, according to Read et al (2001), as Internet economy faces tougher competition for human resources than for financial resources. Besides, the employer-employee relation is one of the most critical factors for e-business success. Value added is created with employees' knowledge and creativity above all and employees' costs represent an adequately high share of total costs. In addition to this, at present much wanted, highly trained professionals achieve very high salaries. Therefore, it is crucial that e-business companies pay a lot of attention to human resources management (HRM) and analysis. Although a lot is written and said about HRM, only a small number of companies actually attempt to systematically and comprehensively measure human capital and its management. One of them is Celemi, a Swedish company that uses Sveiby's Intangible Asset Monitor model (IAM), which places strong emphasis on human capital (Upton, 2001). IAM introduces three groups of human capital indicators: growth/renewal, efficiency and stability.

1. Growth/renewal can be measured by: number of years in the profession, education level, training and education costs, marking, competence turnover, competence-enhancing customers, number of completed projects, number of internal workshops and seminars, number of employees with PC and Internet access.

2. Efficiency can be evaluated by: proportion of professionals, leverage effect, value added per employee or per professional, profit per employee or per professional, revenues per employee or per professional, revenues per employees costs, labor costs per employee. Beside efficiency, effectiveness can be measured by indicators like new visitors/users/customers per employee, website's stickiness (for measuring web designers and content creators effectiveness).

3. Stability of employees can be observed through: professionals' turnover (by organizational units, by professional profile, by reasons for leaving etc.), relative pay, seniority, and employee satisfaction index. 


\subsection{Intangibles}

New economy companies depend heavily on intangible assets. When analyzing intangibles and also a company's business performance, we face the problem of accounting recognition of intangibles. Namely, only some of them may be included in company's balance sheet, others must be recognized as costs. One can distinguish three kinds of intangibles: intangibles that may be reported on balance sheets (i. e. intangibles purchased or those whose value can be reasonably estimated on secondary markets), intangibles that may not be reported on balance sheets (e.g. internally developed brand names, marketing expenditure) and intangibles that even do not correspond to the accounting definition of intangible assets, but are in fact a very important business asset (e.g. customer loyalty). The "intangibles problem" is not particularly urgent for traditional business. However, it is much more obvious and significant for e-business, as these companies use almost exclusively intangible assets to create value, revenues and profit. If BPA is based on accounting data, we get a rather distorted image of company's performance. It appears that company's revenues are generated by almost "nothing". For example, the ratio between revenues and fixed assets for selected Canadian traditional companies was between 0.4 and 0.9 , while the same ratio for software companies was between 3.5 and 6.7 (McLean, 1995).

In general, companies are suggested to measure the amount, structure, dynamics and value of intangibles, as well as company's effectiveness and efficiency at creating and using intangibles. There are very few specific measures for estimating (in literature and in practice), some of them are: number of patents, investments in ICT, investments in $\mathrm{R} \& \mathrm{D}$, brand awareness indices and the like. It is much more common, at least in literature, to measure the total value of intellectual capital, including intangibles. A number of approaches have been developed to measure the value of intellectual capital: market-to-book ratio, Tobin's q ratio, Strassmann's knowledge capital value (Strassmann, 1999), calculated intangible value (Sawhney et al., 2001), Lev's Knowledge Capital Scoreboard ${ }^{\circledR}$ (Eccles et al., 2001) and PriceWaterhouseCoopers LLP overall value (Sawhney et al., 2001).

\subsection{Finance}

Financial performance of a company is essentially determined by three factors: revenue growth and structure, costs' reduction and assets usage efficiency. If we apply Kaplan and Norton's suggestions for companies in growth phase (Kaplan and Norton, 2001), which is the case of e-business companies, they should concentrate more on revenue growth and structure, than on cutting costs. Authors believe that these companies should therefore focus on introducing new products or services, expanding capacities and acquiring new customers and markets. Some well-known measures are: sales growth rates by products, market segments, revenue sources etc. Instead of improving company's performance through cost cutting, management should seek ways to increase productivity (measured e.g. by revenues per employee). At this point, we would like to point out the high proportion of fixed costs (high operating leverage), usually associated with e-business companies. Since companies in growth stage usually do not make profit, it is not sensible to use profitability ratios to measure assets usage efficiency. Instead, Kaplan and Norton (ibidem) suggest other measures, like investments to sales ratio, R\&D expenditures to sales. E-business and Internet companies often use measures described in customers' analysis section (number of users, conversion rate etc.) and various sales growth rates. These can give reasonable estimations in the short term, for the long term; however, profitability must be taken into consideration. 
Table 3.: A summary of measures appropriate for e-BPA.

\begin{tabular}{|c|c|c|}
\hline \multirow{3}{*}{ Customers } & \begin{tabular}{|l|} 
Visitor \\
acquisition \\
\end{tabular} & $\begin{array}{l}\text { Total site reach, number of visitors, acquisition costs per visitor, frequency (number of } \\
\text { visits per visitor) and duration (average duration of visit), stickiness, freshness factor. }\end{array}$ \\
\hline & Conversion & $\begin{array}{l}\text { Number of customers, customer acquisition cost, customer conversion rate, number of } \\
\text { transactions per customer, revenue per transaction and per customer, operating income } \\
\text { per customer, the ratio of abandoned shopping carts to completed purchases per day, the } \\
\text { number of items and their profile in abandoned carts vs. items in completed purchases, } \\
\text { the profile of a shopper vs. a buyer. }\end{array}$ \\
\hline & $\begin{array}{l}\text { Customer } \\
\text { retention }\end{array}$ & $\begin{array}{l}\text { Number of repeat-customers, repeat-customer acquisition cost, repeat-customer churn } \\
\text { rate, number of transactions per repeat-customer, revenue per transaction and per repeat } \\
\text { customer. }\end{array}$ \\
\hline \multirow{3}{*}{$\begin{array}{l}\text { Operational } \\
\text { excellence }\end{array}$} & Inbound logistics & $\begin{array}{l}\text { Total duration of the process, share of incorrect or untimely supplies, number of input } \\
\text { shortage cases (by reason), share of electronically provided inputs, share of e- } \\
\text { procurement costs in total procurement costs, share of suppliers with whom e- } \\
\text { procurement is established, inventory level and turnover, costs, prices and business terms } \\
\text { achieved by doing business electronically vs. traditionally. }\end{array}$ \\
\hline & Operations & $\begin{array}{l}\text { Total duration of the operation process, total time to complete customer's order, time to } \\
\text { load a web page, logicality of website structure (the share of users that do not follow the } \\
\text { expected click-path, the number of "unnecessary" clicks made by users, the share of users } \\
\text { that discontinued the process), time to make an order (how much typing needs to be done } \\
\text { by user), the percentage of improperly or untimely fulfilled orders, maximum number of } \\
\text { orders that can be processed simultaneously, percentage of orders that can be } \\
\text { processed/fulfilled online, percentage of cases of data unavailability due to company's } \\
\text { server error, percentage of cases of inability to fulfill orders. }\end{array}$ \\
\hline & $\begin{array}{l}\text { Delivery, sales } \\
\text { and service }\end{array}$ & $\begin{array}{l}\text { Time to make an order, the percentage of improperly fulfilled orders, share of customers } \\
\text { that place orders electronically/online, orders' status, share of customers that are billed } \\
\text { electronically/online, share of customers that pay electronically/online, time to execute } \\
\text { online payment, number of payment transaction errors, share of transactions settled by } \\
\text { barter agreements, receivables turnover, time necessary to deliver the product or service } \\
\text { to the customer, share of untimely and/or incorrect deliveries, delivery costs covered by } \\
\text { company and by customers, time necessary to solve customers' (product related) prob- } \\
\text { lems, share of responses to customer's first time request, customers' time spent on sup- } \\
\text { port web pages, costs related to service. }\end{array}$ \\
\hline \multirow{3}{*}{$\begin{array}{l}\text { Human } \\
\text { capital }\end{array}$} & Growth/renewal & $\begin{array}{l}\text { Number of years in the profession, education level, training and education costs, marking, } \\
\text { competence turnover, competence-enhancing customers, number of completed projects, } \\
\text { number of internal workshops and seminars, number of employees with PC and Internet } \\
\text { access. }\end{array}$ \\
\hline & Efficiency & $\begin{array}{l}\text { Proportion of professionals, leverage effect, value added per employee or per profession- } \\
\text { al, profit per employee or per professional, revenues per employee or per professional, } \\
\text { revenues per employees costs, labor costs per employee, new visitors/users/customers per } \\
\text { employee, website's stickiness. }\end{array}$ \\
\hline & Stability & $\begin{array}{l}\text { Professionals turnover (by organizational units, by professional profile, by reasons for } \\
\text { leaving etc.), relative pay, seniority, employee satisfaction index. }\end{array}$ \\
\hline \multirow[b]{2}{*}{ Intangibles } & Intangibles & Number of patents, investments in ICT, investments in R\&D, brand awareness indices. \\
\hline & $\begin{array}{l}\text { Intellectual } \\
\text { capital value }\end{array}$ & $\begin{array}{l}\text { Market-to-book ratio, Tobin’s q ratio, Strassmann's knowledge capital value, calculated } \\
\text { intangible value, Lev's Knowledge Capital Scoreboard }{ }^{\circledR} \text { and PriceWaterhouseCoopers } \\
\text { LLP overall value. }\end{array}$ \\
\hline \multirow{4}{*}{ Finance } & \begin{tabular}{|l|}
$\begin{array}{l}\text { Revenue growth } \\
\text { and structure }\end{array}$ \\
\end{tabular} & Sales growth rates by products, market segments, and revenue sources. \\
\hline & Costs reduction & Revenues per employee \\
\hline & \begin{tabular}{|l} 
Assets usage \\
efficiency
\end{tabular} & Investments to sales ratio, R\&D expenditures to sales, number of users, conversion rate. \\
\hline & Liquidity & Cash burn rate \\
\hline
\end{tabular}


There is a difference between working capital investment in e-business companies and traditional ones. Some e-business companies have negative investments in working capital, which effectively means that customers finance inventories (negative difference between days receivables outstanding and days payables outstanding). This occurs because electronic business and Internet business models reduce inefficiencies related to relationships with customers and suppliers and shorten the time necessary to complete transactions. Another often-used liquidity measure is the cash burn rate, which is used to calculate how long can a company survive at the present rate of cash spending.

We conclude this section with a synoptic table of measures, described previously. They can be used in addition to traditional analytic measures and ratios, when analyzing e-business companies.

\section{Conclusion}

In the first section of the paper we established that CEE companies increasingly use and recognize the need for e-business. As the number of Internet users and e-shoppers in the population still rises, there is also some more potential for economic opportunities. On the other hand, judging by the case of Slovenian companies, we could say that most e-business companies are limited to fairly simple operations, such as the use of Internet for information gathering and communication. The use of e-business in operational business processes is rare, even in the case of eshops, where in most cases only the communication with end consumers is carried out over the Internet (advertising, ordering). Overall, only a small part of companies generate revenues from e-business, in most cases these are rather negligible. Companies quote financial and human resources shortage as important obstacles for greater use of ebusiness.

We could speculate that most CEE companies engage in e-business projects primarily for experimental as opposed to commercial purposes: they want to get some experiences and wait, before investing larger amounts of resources into more sophisticated e-business applications. The most important factor to analyze in this phase is, in our opinion, the customers' factor. It is here that the biggest changes occur, as the operational processes are usually not carried out electronically, the financial aspect is currently somewhat less important, because these are not strictly commercial projects. Intangibles and human capital are important, but difficult to measure and evaluate even in traditional companies. It is the success at attracting and retaining visitors and buyers (even more) that is crucial for project's present and future life. Therefore it is necessary to carefully monitor customer area now to identify and evaluate future options.

\section{References}

1. Adams Chris et al.: Managing with Measures, Measuring eBusiness Performance. Accenture, 2000 - 2001.

2. Agrawal Vikas et al.: E-performance: The Path To Rational Exuberance. McKinsey \& Company, The McKinsey Quarterly, Number 1, 2001.

3. Bennet Madeline: Steps To Faster Procurement. IT Week, November 12, 2001. URL: [http://www.zdnet.co.uk/itweek/analysis/2001/43/internet].

4. Cisco Corporation: Internet Corporation: Internet Value Matrix. URL: [http://www.cisco.com/ warp/public/750/icorporation/matrix.html], retrieved from Internet 12.02.2001.

5. $\quad$ Computer Industry Almanac Inc.: U.S has 33\% Share of Internet Users Worldwide Year-end 2000. Computer Industry Almanac Press Release, 2001. URL: [http://www.c-i-a.com/pr0401.htm].

6. Coppel Jonathan: E-commerce: Impacts and Policy Challenges. OECD Economic Department Working papers No. 252, Paris, June 2000.

7. Cutler Matt, Sterne Jim: E-Metrics, Business Metrics For The New Economy. NetGenesis Corp., 2000. URL: [http://www.netgen.com/emetrics].

8. Donath Bob: The Quest for eBusiness Frameworks, Measuring and Tracking eBusiness Strategies, EBusiness Workshop White paper. The Pennsylvania State University, eBusiness Research Center (eBRC), March 1999.

9. $\quad$ Eccles Robert G. et al.: The ValueReporting ${ }^{T M}$ Revolution: Moving Beyond the Earnings Game. John Wiley \& Sons, Inc., New York, 2001. 
10. ESIS Project Management Support Team: ESIS II Report: Information Society indicators in the Countries of Central and Eastern Europe. A report prepared for the DG Information Society, January 2001. [http://europa.eu.int/ISPO/esis/default.htm].

11. Eurostat: E-Commerce in Europe, Results of the Pilot Surveys Carried Out in 2001. Eurostat, July 2002. URL: [http://europa.eu.int/comm/enterprise/ict/studies/lr-e-comm-in-eur-2001.pdf].

12. Feindt Sylvie, Culpin Ian: Electronic Commerce and Secure Telecommunications. Draft Final Report to STOA, May 1998.

13. Hobley Christopher: Just Numbers, Numbers on Internet Use, Electronic Commerce, IT and Related Figures for the European Community. European Commission DG Information Society, January 2001.

14. Jerman Blazic Borka et al.: Elektronsko poslovanje na internetu (in Slovenian, engl. Electronic business on Internet). GV Založba, Ljubljana, 2001.

15. Kaplan Robert S., Norton David P.: Strateško usmerjena organizacija, Praktična uporaba uravnoteženega sistema kazalnikov v novem poslovnem okolju (Slovenian translation of The strategy-focused organization: how balanced scorecard companies thrive in new business environment). GV Založba, Ljubljana, 2001.

16. Kaplan Robert S., Norton David P.: The Balanced Scorecard: Translating Strategy Into Action. Harvard Business School Press, Boston (Massachusetts.), 1996.

17. McConnell International LLC.: Risk E-Business: Seizing the Opportunity of global E-Readiness. August 2000. URL: [http://www.mcconnellinternational.com/ereadiness/EreadinessReport.htm].

18. McLean Robert I. G.: The Canadian Performance Reporting Initiative, Performance Measures in the New Economy. 1995. URL: [http://cpri.matrixlinks.ca/Archive/PMNE/PerfMeasNE.html].

19. Melymuka Kathleen: Measuring your online profitability. The Australian Industry Standard, The Newsmagazine of the Internet Economy, 7. September 2001. URL: [http://www.thestandard.com.au/ articles/display/0,1449,15120,00.html].

20. Moore Scott: Internet usage and eCommerce in Southeast Europe, 2000-2005. IDC CEMA, 2001. URL: [http://www.idccentraleurope.com/promo/promo.php?report=8].

21. Netcraft Inc.: SSL Surveys. January 2001. URL: [http://www.netcraft.com/surveys/analysis/ https/2001/Jan/index.html].

22. Netstatistica: Are You Ready For Xmas 2001? December 2001. URL: [http://www.netstatistica.com].

23. OECD: OECD Information Technology Outlook 2000, ICTs, E-commerce and the Information Economy. OECD, Paris, 2000.

24. Pučko Danijel: Analiza poslovanja (in Slovenian, engl.: Business Analysis). University of Ljubljana, Faculty of Economics, Ljubljana, 2001.

25. Read Cedric et al.: eCFO, Sustaining Value in the New Corporation. John Wiley \& Sons, Ltd., Chichester, 2001.

26. RIPE: RIPE Region Hostcount. June 2002. URL: [http://www.ripe.net/ripencc/pubservices/stats/hostcount/2002/06/pen-sort.all-tld-pop.htm].

27. RIS 2000/2001: e-nakupovanje končnih potrošnikov (in Slovenian, engl.: RIS 2000/2001: e-shopping by end consumers). University of Ljubljana, Faculty of Social Sciences, Center for methodology and informatics, Project RIS, Ljubljana, July 2001

28. Sawhney Mohan et al.: TechVenture, New Rules on Value and Profit from Silicon Valley. John Wiley \& Sons Inc., New York, 2001.

29. Stern Stewart and Co., Razorfish Inc.: Digital Value Added. URL: [http://www.sternstewart/dva], retrieved from Internet in February 2001.

30. Strassmann Paul A.: Measuring and Managing Knowledge Capital. Knowledge Executive Report, Knowledge Executive Inc., 1999. URL: [http://www.strassmann.com/pubs/measuring-kc] retrieved from the Internet 04.02.2001.

31. Tekavčič Metka: Analiziranje v pogojih elektronskega poslovanja (in Slovenian, engl.: Business Analysis in e-business Environment). Strokovno posvetovanje o sodobnih vidikih analize poslovanja in organizacije, Zveza ekonomistov Slovenije, Sekcija za poslovne analize, Portorož, 2000.

32. The Center for Democracy and Technology: A Briefing on Public Policy Issues Affecting Civil Liberties Online. CDT Policy Post, Volume 6, Number 9, April 2000.

33. The Center for Democracy and Technology: Bridging the Digital Divide: Internet Access in Central and Eastern Europe, Country Details. URL: [http://www.cdt.org/international/ceeaccess/ countrydetail. shtml]. 
34. United States Agency for International Development: Croatia ICT Assessment. September 2000. URL: [http://www.usaid.gov/regions/europe_eurasia/pdfs/crictpub.pdf].

35. United States Internet Council \& IITA Inc.: State of the Internet 2000. URL: [http://usic.wslogic.com/intro.html].

36. Upton Wayne S., Jr.: Business and Financial Reporting, Challenges From the new Economy. Financial Accounting Standards Board, April, 2001.

37. Vasja Vehovar, Jana Murgelj: Uporabniki Interneta 2001 (in Slovenian, engl.: Internet Users 2001). University of Ljubljana, Faculty of Social Sciences, Center for methodology and informatics, Project RIS, Ljubljana, October 2001.

38. Vehovar Vasja: Je slovenski trg za Internet premajhen? (in Slovenian, engl.: Is The Slovenian Market Too Small For Internet?). University of Ljubljana, Faculty of Social Sciences, Center for methodology and informatics, Project RIS, Ljubljana, 2000.

39. VIP: Internet surveys, Round 5 results, Extracts from the primary results. June - July 2000. URL: [http://www.park.cz7pruzkum7e7round5.htm].

Notes 